\title{
Teachers' Perception on The Development of Local History Digital Teaching Material in Surakarta
}

\author{
Leo Agung $S$ \\ Postgraduate of History Education Department \\ Teacher Training and Education Faculty \\ Sebelas Maret University \\ Surakarta, Indonesia \\ leoagung@staff.uns.ac.id
}

\author{
Muhammad Akhyar Akhyar \\ Postgraduate of History Education Department \\ Teacher Training and Education Faculty \\ Sebelas Maret University \\ Surakarta, Indonesia \\ muhammadakhyar@staff.uns.ac.id
}

\begin{abstract}
Technology utilization supports global information current to be accessible through internet. This condition is in contradiction with the limited access to information about local history. Students' emotional closeness to surrounding environment is a historical learning source valuable to the learning process in the class. For that reason, the local historical development should utilize digital technology. History teacher is one of main components in the learning process utilizing digital book. This research aimed to describe history teachers' perception on the development of local history digital material. Qualitative method was employed in this study. Data collection was carried out using interview and questionnaire to explore the respondents' view on the development of local history digital material. The subject of research consisted of 20 history teachers in Surakarta. Data analysis was carried out using an interactive model of analysis. The findings of research showed that history teachers in Surakarta had positive perception on the development of local history digital material. Teachers were motivated to utilize technology in the learning. The main constraint included limited number of writings on local history in Surakarta and teachers' inadequate ability of mastering IT.
\end{abstract}

Keywords-teachers' perception, teaching material, local history, and digital book.

\section{INTRODUCTION}

The current development of science and technology has a tremendous impact on the life of society. This swift increase in technology use has also affected educational systems (Erkhan, 2013). In this modern era of learning, it can not be separated from the use of technology. Utilization of textbooks as one source of learning according to teachers, making learning becomes textual and it is not effective (Jaedun, 2010). The Internet offers an alternative way as a source of learning for learners, especially in High School in Indonesia. The Internet is expected to provide support for the implementation of an interactive communication process between teachers and students. Improving the ability and awareness of teachers to recognize and master the technology by making learning media based on digital teaching materials become more interesting, communicative, adaptive and the most principles can connect learners to a real and meaningful understanding (Wathy, 2017). Thus, learners can use information and communication technology tools in the form of digital teaching materials, to explore, seek, analyze and exchange information efficiently and effectively (Anshori, 2017). In addition, the digital world is also served as an alternative in delivering more innovative knowledge (GrandClement, 2017).

Utilization of technology supports global information easily to be accessed via the internet quickly. This condition is in contrast to the lack of access to information about local history. Whereas local history events in the environment of learners have a role as: (1) character building; (2) social solidarity, and (3) social reconciliation vehicle (Sulistiyono, 2009). Students' emotional is close to environment ad it is a valuable source of historical learning for the learning process in the classroom. As Beck puts it in Nana Supriatna stating that every individual or community group has excellence and local genius or center of scholarship and become central tradition of scholarship (Supriatna, 2007). Historical teachers are one of the main components in the learning process using digital books. Teachers as facilitators in the learning process will be better if they can offset the ability of students in mastering technology. So the teacher is required to create an active and fun learning history through providing innovative historical learning media. One of history's innovative learning media is digital books based on local history. Utilization of digital books in the learning of local history as an effort to realize the learning of history as intellectual training, as well as moral education of the nation and civil society. This 
research discuss about: (1) the ability of teachers in the use of digital teaching materials; and (2) the use of ICT in the learning process of history; (3) teachers' perception of the development of local digital history materials; (4) the teacher's opinion on the expected local digital history materials.

\section{RESEARCH METHOD}

This research was a qualitative research. The research subjects consisted of 20 teachers of history subjects of Senior High School in Surakarta, Central Java, Indonesia. Samples were chosen using purposive sampling. Data were collected using questionnaires and interview sheets. Questionnaires were designed to determine the learning condition and learning resources that had been used. The interview was conducted to confirm the results of the questionnaire which had been answered. Some statements from the questionnaire are statements developed by the researchers themselves.

The statements developed by researchers related to the type of teaching materials, especially in teaching local history. Questionnaires were divided into large groups namely: (1) the ability of teachers in the use of digital teaching materials; and (2) the use of ICT in the learning process of history; (3) teachers' perception of the development of local digital history materials; (4) the teacher's opinion on the expected local digital history materials. Interactive analysis was used as data analysis technique. Validity of data this research used triangulation, namely checking the validity of data by utilizing something else beyond the data for checking or comparison purposes (Moleong, 2009). Triangulation used including methods and sources.

\section{RESULT AND DISCUSSION}

\section{A. The ability of teachers in using digital teaching materials}

Instruments were used to measure how the ability of teachers in using digital teaching materials. The ability of teachers in using teaching materials to make sure whether the teacher is ready with new learning methods. The categories used are: VO (Very Often), O (Often), N (Neutral), NO (Not Often), VNO (Very Not Often). The instrument results are described in the table below:

TABLE 1 Teacher's ability to plan lessons

\begin{tabular}{|l|c|c|c|c|c|}
\hline \multicolumn{1}{|c|}{ Indicator } & VO & O & N & NS & VN \\
O
\end{tabular}

\begin{tabular}{|l|c|c|c|c|c|}
\hline $\begin{array}{l}\text { Teachers always created } \\
\text { flexible and innovative } \\
\text { learning }\end{array}$ & 8 & 9 & 3 & - & - \\
\hline $\begin{array}{l}\text { Teachers always } \\
\text { facilitated access to } \\
\text { information }\end{array}$ & 5 & 13 & - & 2 & - \\
\hline $\begin{array}{l}\text { Teacher always created } \\
\text { collaborative learning }\end{array}$ & 6 & 13 & - & 4 & - \\
\hline $\begin{array}{l}\text { Teachers always } \\
\text { provided learning tools } \\
\text { or information tools } \\
\text { complete }\end{array}$ & 8 & 7 & 3 & 2 & - \\
\hline \multicolumn{1}{|c|}{ Total } & $\mathbf{4 5}$ & $\mathbf{6 1}$ & $\mathbf{9}$ & $\mathbf{8}$ & - \\
\hline Percentage (\%) & $\mathbf{3 6 , 6}$ & $\mathbf{4 9 , 5}$ & $\mathbf{7 , 4}$ & $\mathbf{6 , 5}$ & - \\
\hline
\end{tabular}

Source: primary data

TABLE 2 Teachers' ability to plan lessons using digital teaching

\begin{tabular}{|l|c|c|c|c|c|}
\hline \multicolumn{1}{|c|}{ Indikator } & VO & O & N & NS & $\begin{array}{c}\text { VN } \\
\text { O }\end{array}$ \\
\hline $\begin{array}{l}\text { Teacher prepares lesson } \\
\text { planning }\end{array}$ & 11 & 6 & 3 & - & - \\
\hline $\begin{array}{l}\text { Teachers identify } \\
\text { learning problems }\end{array}$ & 8 & 9 & 3 & - & - \\
\hline $\begin{array}{l}\text { Teachers prepare } \\
\text { learning design }\end{array}$ & 4 & 14 & - & 2 & - \\
\hline $\begin{array}{l}\text { Teacher continues to be } \\
\text { innovate in learning }\end{array}$ & 8 & 11 & - & 4 & - \\
\hline $\begin{array}{l}\text { Teachers using the } \\
\text { application of digital } \\
\text { teaching materials in the } \\
\text { learning process }\end{array}$ & 8 & 8 & 2 & 2 & - \\
\hline \multicolumn{1}{|c|}{ Total } & $\mathbf{3 9}$ & $\mathbf{4 8}$ & $\mathbf{8}$ & $\mathbf{8}$ & - \\
\hline \multicolumn{1}{|c|}{ Percentage (\%) } & $\mathbf{3 7 , 8}$ & $\mathbf{4 6 , 6}$ & $\mathbf{7 , 7}$ & $\mathbf{7 , 7}$ & - \\
\hline
\end{tabular}

Source: primary data

From table 1 above, it can be seen that $36,6 \%$ of teacher very often and $49.5 \%$ of teachers often do the planning of learning. So it can be concluded that teachers have used new strategies and methods in learning. The use of new strategies and methods in learning process is very important. Strategies and new methods which used one of them by using technology in the learning process. The use of technology in the learning process has some advantages namely: (1) achieve the effectiveness of learning; (2) providing a set of media and tools for streamlining students' work; (3) students prefer to follow the learning; and (4) evoke positive students' emotions in the learning process (Suryadi, 2007). Appropriate learning strategies and methods support flexible, innovative learning and improve time efficiency in learning. Thus, the impact on students to be more active and creative in following the learning process, especially history learning.

Future education requires collaborative learning supported by technology. The younger generation who grew up with technological prosperity have cognitive and affective abilities that are characteristically different from the adult generation (Suh, 2011). The results of educational reform can be 
seen with what has been achieved by students in order to improve the ability to learn to master the higher nobility. Teacher as facilitator has an important role in creating active and invotive learning. Use of new strategies and methods in learning by making use of technologies such as digital teaching materials are an innovation in learning as a form of increased motivation and selfconcept.

Table 2 above showed that $37,86 \%$ of teachers very often and $46,6 \%$ of teacher often plan the learning using digital teaching materials. The conclucion, guru have been planning lessons using digital teaching materials well. The planning process includes: (1) planning; (2) identification of learning problems; (3) preparing the design; (4) innovation; and also (5) using the application of digital teaching materials in the learning process. Lesson plan is a written description for this process; where the materials, the method, the time and the place of education as well as methods for evaluating the students are described in detail. Lesson plan is one option for teachers to manage the class properly (Nesari, 2014).

The framework for effective professional learning is based on the following seven principles: (1) have a clear, well-defined purpose of what it is aspiring to achieve; (2) allow teachers opportunities to build on their knowledge and skills; (3) model with examples the strategies to be taken to the classroom and used by the teachers; (4) be part of the continuous development of the learning community; (5) provide opportunities for teachers to lead reform efforts; (6) help provide links to other parts of the education system; and (7) consistently review its success in meeting its objectives and ensuring a positive impact on teachers' effectiveness and students' learning and attitude (Rachel Sheffield, 2018).

\section{B. The use of ICT in historical learning}

The process of digging information to obtain data how teachers use ICT in the process of learning information was done using interview methods and document review. From the data above, it showes that $80 \%$ of teachers agreed that technology supports the teaching process. As Buket and Erkhan's research mentioned the use of one smart board technology: (1) increasing students' motivation and participation; (2) time efficiency; (3) effective learning with visual material (Erkhan 2013, 74-75).

As many as $90 \%$ of teachers claimed to use ebooks in the learning process. So it can be concluded that the teachers had used other teaching materials other than textbooks. Teachers as much as $75 \%$ stated that the use of digital teaching materials as one source of learning is also important, $25 \%$ said it is not important to use digital teaching materials because it is not familiar. The use of digital teaching materials will help students understand the concept of history lesson material faster, students are also more active in following the learning in the classroom.

As many as $45 \%$ of teachers stated that using ICT is convenient to be used in teaching and learning, while $55 \%$ say it is uncomfortable to be used. It is constrained on: (1) unaccustomed to use ICT; (2) inadequate facilities and infrastructure; (3) limited time; (4) limited students' ability.

Nevertheless, the teachers agreed to develop teaching materials based on digital history. This is because teachers want innovative and interesting learning for students, local history materials, which are not localized in textbooks provided by the government.

TABLE 3 Teachers' opinions on the use of ICT in the learning process of history

\begin{tabular}{|l|c|c|}
\hline \multicolumn{1}{|c|}{ Questionnaire } & Answers (\%) \\
\cline { 2 - 3 } & Yes & No \\
\hline $\begin{array}{l}\text { Does the use of technology support teaching } \\
\text { methods? }\end{array}$ & 80 & 30 \\
\hline $\begin{array}{l}\text { Does using e-book facilitate communication } \\
\text { with students? }\end{array}$ & 90 & 10 \\
\hline $\begin{array}{l}\text { Is the use of digital teaching materials very } \\
\text { important as a teaching material? }\end{array}$ & 75 & 25 \\
\hline $\begin{array}{l}\text { Does the use of digital teaching materials help } \\
\text { students understand the concept of history } \\
\text { lesson material more quickly? }\end{array}$ & 70 & 30 \\
\hline $\begin{array}{l}\text { Is the use of digital teaching materials in } \\
\text { learning history will make students more active } \\
\text { in following the learning? }\end{array}$ & 75 & 25 \\
\hline $\begin{array}{l}\text { Do teachers feel comfortable using ICT as a } \\
\text { tool in teaching and learning? }\end{array}$ & 45 & 55 \\
\hline $\begin{array}{l}\text { Has it been using digital-based history teaching } \\
\text { materials? }\end{array}$ & 5 & 95 \\
\hline
\end{tabular}

Source: primary data

\section{Teachers' perception of the development of local digital history materials}

Teacher's perception of the development of local digital history materials excavated by interviewing. The result were $90 \%$ of teachers mention that teaching local history is very important for students. Local history event in school tuition have an important role to actualizing learning element and education. Proximity student's emotional with their surroundings is source of valuable learning of history for process teaching history. The result of study John Callewaert mention the important role of local history for informing public policy initiatives seeking to address environmental inequities (Callewaert, 2002).

The main constraint teacher to teaching local history i.e limited number of writings on local history in Surakarta. The writing of local history limited to a particular locality that a document regarding the 
development of an area in certain periode (Syafi'i, 2017). Semith Atekin exlplain that to get maximum benefits of local history studies for history education, topics and methods should be chosen very carefully (Aktekin, 2009). The principle must be maintained is as follows:

1) Local history is resource-led: Teachers should find out the possible available sources in a particular topic and then decide whether or how to focus upon it. Teachers should know whether there is sufficient or appropriate evidence to support an educational enquiry.

2) Local history should be child-centred: The teacher should allow pupils to do more work than himself/herself. Teachers' main role should be supporting students' enquiries.

3) Local history should be enquiry-led: Researching familiar local areas can give students good opportunities to 'act as historians' and teachers should use this opportunity widely.

4) Use the widest range of historical sources possible: Local history studies can use different sources such as, museum and site visits, oral history, artefacts, maps, photographs, pictures, publications, and printed and hand-written documents. The teacher should highlight them and discuss them with students.

5) Find romance: Most children love a mystery and finding small clues such as 'faded lettering on a wall, a bump in a field, an entry in a school logbook, a name on a map' (Bage, 2000) can attract them and lead them into wanting to know more.

6) Evaluate evidence: Local history projects should evaluate evidences during the project. Some localities can have legendary stories of local buildings and events. Local history projects can collect them as well but they should try to be tested.

7) Involve local experts: Local authors, amateur archaeologists, archivists, antique dealers, builders or architects, radio or newspaper journalists might have interesting stories and expertise. Their expertise and knowledge should be included in local studies.

8) Involve local community: Sources from local community such as, record offices, libraries, websites, buildings, parish magazines or newsletters, letters home, contacts with ex-teachers or pupils, local history groups, local newspapers and supplements, the church, old people's homes etc. can be interesting information sources.

9) Aim for an end-product : The results of any local history project can be shared in many ways: an exhibition, open evening, publication, school museum, radio programme and group presentation in assembly. Those activities are educationally beneficial and also they can give the local community something back and improve the image of the school (Aktekin, 2009).

\section{Teacher's opinion on the expected digital teaching materials}

To obtain data about teachers' opinions about digital materials which are expected to be done by holding Focus Group Discussion / FGD. When FGD teachers convey the obstacles faced so far in the learning process of history. During this time teachers still use textbooks, so that students are less interested in following the lesson. To overcome this, teachers have a positive perception of the development of local and motivated digital history material to utilize technology in history learning. The main obstacles faced by teachers are the limited number of local history writing in Surakarta and inadequate mastery of teachers. Collaboration to develop local history of digital history in Surakarta is needed.

\section{CONCLUSION}

The result of this research showed that history teachers in Surakarta have a positive perception of the development of local digital history materials. Teachers in the learning process of history so far is still minimal use of digital teaching materials. As a result, students are less active and interested in following the process of teaching and learning in the classroom. To create innovative and fun learning, the teachers agreed to develop teaching materials based on digital history. One of them is by using local history of digital teaching materials. Teachers mention that teaching local history is very important for students. Constraints faced by teachers are: (1) limited number of writing about local history in Surakarta; (2) inadequate ability of ICT mastery; and (3) limited local digital history, especially local history in Surakarta. To overcome the problem requires collaboration between teachers and researchers to develop digital materials based local history learning in Surakarta.

\section{REFERENCES}

[1] Aktekin, S. (2009). The Place and Importance of Local History in the Secondary History Education. Journal of Theory and Practice in Education, 86-105.

[2] Anshori, S. (2017). Pemanfaatan TIK sebagai Sumber dan Media Pembelajaran di Sekolah. Civic-Culture: Jurnal Ilmu Pendidikan PKn dan Sosial Budaya , 10-20.

[3] Bage, G. (2000). Thinking History 4.14 Teaching, learning, curricula and communities . London: Routledge/ Falmer.

[4] Callewaert, J. (2002). The Importance of Local History for Understanding and Addressing Environmental Injustice. The International Journal of Justice and Sustainability , 257-267.

[5] Grand-Clement, S. (2017). Digital Learning: Education and Skills in The Digital Age. London: the RAND Corporation, Santa Monica, Calif., and Cambridge, UK.

[6] Jaedun, A. (2010). Pemanfaatn Teknologi Informasi dan Komunikasi sebagai Sumber Belajar Alternatif. Diklat 
Pemanfaatan Sumber Belajar yang Kreatif (pp. 1-14). Yogyakarta: Jogya Cendekia.

[7] Moleong, L. J. (2009). Metodologi Penelitian Kualitatif. Bandung: Remaja Rosdakarya.

[8] Nesari, A. J. (2014). The Important Role of Lesson Plan on Educational Achievement of Iranian . International Journal of Foreign Language Teaching \& , 25-31.

[9] Rachel Sheffield, S. B. (2018). A Professional Learning Model Supporting Teachers to Integrate Digital Technologies. Issues in Educational Research, 487-510.

[10] Suh, H. (2011). Collaborative Learning Models and Support Technologies in the Future Classroom. International Journal for Educational Media and Technology , 50-61.

[11] Sulistiyono, S. T. (2009). Penulisan Sejarah Lokal di Era Otonomi Daerah: Metode, Masalah dan Strategi. Seminar Nasional Peningkatan Kompetensi Penelitian untuk Pengajaran Sejarah di Era Sertifikasi dan Otonomi Daerah (pp. 1-10). Kudul: Masyarakat Sejarahwan Indonesia.

[12] Supriatna, N. (2007). Konstruksi Pembelajaran Sejarah Kritis Bandung: Historia Utama Press.

[13] Suryadi, A. (2007). Pemanfaatan ICT dalam Pembelajaran. Jurnal Pendidikan Terbuka dan Jarak Jauh , 83-98.

[14] Syafi'i, I. (2017). Sejarah Lokal adalah Sejarah Maritim (Nasional) Indonesia. Sejarah dan Buday, 23-36.

[15] Wathy, R. (2017, Maret 09). Teknologi Informasi sebagai Sumber Belajar . Retrieved Mei 25, 2018, from Zona TIK 98: http://rahmawhaty22.blogspot.co.id/2017/03/teknologi-

informasi-sebagai-sumber.html 